\title{
KEJAHATAN PEDOFILIA SEBAGAI PERILAKU MENYIMPANG DAN UPAYA PENEGAKAN HUKUMNYA
}

\author{
Delvina Alodia $^{1}$, Jesslyn ${ }^{2}$, Vini Anggreini ${ }^{3}$ \\ ${ }^{1}$ Fakultas Hukum, Universitas Tarumanagara, Jakarta \\ Email: delvina.alodia@yahoo.com \\ ${ }^{2}$ Fakultas Hukum, Universitas Tarumanagara, Jakarta \\ Email: jesslynblue96@gmail.com \\ ${ }^{3}$ Fakultas Hukum, Universitas Tarumanagara, Jakarta \\ Email: vinie.guo@yahoo.com
}

\begin{abstract}
Pedophilia is an obsession with children as sex objects. Overt acts, including taking sexual explicit photographs, molesting children, and exposing one's genitalia to children are all crimes. The problem with these crimes is that pedophilia is also treated as a mental illness, and the pedophiles are often released only to repeat the crimes or escalate the activity to the level of murder. This caused for the victims, in this case the children, and their families to feel insecure as there are still chances that the culprit is still targeting them. And there is also the physical and mental trauma that the children suffer as a result of the illicit act. Therefore pedophilia should be addressed seriously as the lives of children are at stake. Many regulations have been created in order to decrease this crime, but with technology's rapid growth and increase of pedophilia communities that can be found all over the internet, it seems like it would be a long way before the crime could be eradicated completely. Because of that the government along with several other authority figures would occasionally search for sanctions that will hopefully decrease the number of pedophiles.
\end{abstract}

Keywords: Pedophilai, Children, Crime, Regulations, Sanctions.

\begin{abstract}
ABSTRAK
Pedofilia adalah obsesi terhadap anak-anak sebagai objek seks. Tindakan berlebihan, termasuk mengambil foto eksplisit seksual, menganiaya anak-anak, dan mengekspos alat kelamin seseorang kepada anak-anak adalah kejahatan. Masalah dengan kejahatan ini adalah pedofilia juga diperlakukan sebagai penyakit mental, dan pedofil sering dilepaskan hanya untuk mengulangi kejahatan atau meningkatkan aktivitas ke tingkat pembunuhan. Ini menyebabkan para korban, dalam hal ini anak-anak, dan keluarga mereka merasa tidak aman karena masih ada kemungkinan bahwa pelakunya masih menargetkan mereka. Dan ada juga trauma fisik dan mental yang diderita anak-anak sebagai akibat dari tindakan ilegal tersebut. Karena itu pedofilia harus ditangani dengan serius karena nyawa anak-anak dipertaruhkan. Banyak peraturan telah dibuat untuk mengurangi kejahatan ini, tetapi dengan pertumbuhan teknologi yang cepat dan peningkatan komunitas pedofilia yang dapat ditemukan di internet, sepertinya akan jauh sebelum kejahatan dapat diberantas sepenuhnya. Karena itu pemerintah bersama beberapa tokoh otoritas lainnya sesekali akan mencari sanksi yang diharapkan akan menurunkan jumlah pedofil.
\end{abstract}

Kata kunci: Pedofilia, Anak-Anak, Kejahatan, Peraturan, Sanksi.

\section{PENDAHULUAN}

\section{Latar Belakang}

Baru-baru ini terungkap kasus pedofilia yang terjadi pada putri semata wayang penyanyi kondang Nafa Indria Urbach, Mikhaela Lee. Sebenarnya Mikhaela sendiri tidak mendapatkan kekerasan maupun pelecehan secara langsung oleh pelaku, namun terdapat indikasi bahwa bocah tersebut menjadi incaran para pedofil di media sosial. Kasus ini lagi-lagi membuka lebar 
mata masyarakat bahwa pedofilia masih kerap menjadi suatu bahaya bagi anak-anak semenjak terungkapnya kasus Jakarta International School (JIS) yang terjadi beberapa waktu lalu. Banyaknya kasus kekerasan seks terhadap anak dipicu dengan semakin berkembangnya pornografi di dunia maya. Ditambah lagi dengan kebebasan warga untuk mengakses internet memudahkan mereka menyebarkan konten-konten yang berbau pedofil, mencari dan berbagi informasi tentunya juga mempermudahkan mereka melancarkan aksinya. Mereka juga beroperasi di jaringan gelap (dark web) yang rumit dan juga anonim yang dapat melindungi mereka secara maksimal (Tunggal P, 2017). Bukan hanya itu, mereka menggunakan internet dan juga berbagai situs untuk membangun jaringan pedofil yang jumlahnya tidak sedikit. Seperti jaringan pedofil internasional bernama 'Official Candy's Group' yang digunakan untuk menyebarkan konten berupa gambar dan juga video. Menurut Direktur Reskrimsus Polda Metro Jaya Kombes Wahyu Hadiningrat, jaringan internasional tersebut tidaklah mencari keuntungan dalam melancarkan aksi tak berperikemanusiaan itu. Melainkan, hanya untuk memenuhi hasrat seks yang menyimpang (Putra Negara, 2017). Walaupun benar bahwa para pedofil sangatlah hebat dalam menyusun rencana dan melancarkan aksi mereka, namun hal ini juga dikarenakan dengan minimnya pengawasan orang tua terhadap anak mereka, khususnya pada saat mengakses internet. Sebuah penelitian yang dilakukan oleh UNICEF (The United Nations Children's Fund) mengemukakan bahwa sekitar $80 \%$ anak-anak dan juga remaja mengakses internet setiap hari atau paling sedikit seminggu sekali. Penelitian juga mengungkapkan bahwa sekitar 24\% dari populasi anak-anak tersebut berkomunikasi dengan orang tak dikenal melalui internet dan 25\% diantaranya membagikan alamat dan juga nomor telepon rumah mereka. Sedangkan $52 \%$ dari anak-anak di Indonesia telah berpapasan dengan konten pornografi di dunia maya dari iklan dan situs tak mencurigakan yang mereka kunjungi, sedangkan hanya $14 \%$ diantaranya yang mengunjungi situs tersebut secara suka rela (Unicef Indonesia, 2014).

Dari sekian banyak negara di dunia ini, terdapat lima negara yang memiliki tingkat pedofilia tertinggi di dunia, yaitu (Global Moslem, 2017): (1) Inggris. Hampir 5\% bocah di Inggris pernah mengalami pelecehan seksual di mana $90 \%$ di antaranya dilakukan oleh kenalan sendiri. Pada tahun 2012-2013, kepolisian mencatat lebih dari 18.000 kasus pelecehan seksual terhadap bocah di bawah 16 tahun. Pada tahun yang sama 4171 pelecehan dan pemerkosaan dilakukan terhadap bocah perempuan di bawah usia 13 tahun; (2) Afrika Selatan. Menurut penelitian Trade Union Solidarity Helping Hand, setiap tiga menit seorang bocah diperkosa di Afrika Selatan. Studi laín mengungkap satu dari empat laki-laki mengaku pernah memperkosa seseorang dan sepertiganya meyakini perempuan menikmati pemerkosaan. Beberapa korban pemerkosaan bahkan baru berusia enam bulan. Korban juga sering terinfeksi HIV/AIDS setelah diperkosa; (3) India. Asian Centre for Human Rights melaporkan pelecehan seksual kepada anak-anak sedang mewabah di India. Laporan terakhir menyebut ada lebih dari 48.000 bocah yang diperkosa selama sepuluh tahun sejak 2001. Tahun 2011 saja kepolisian mencatat 7112 kasus pemerkosaan anak-anak. Menurut IB Times, pelaku pemerkosaan anak di India mencakup ayah, saudara, tetangga, dan guru sekolah; (4) Zimbabwe. Kepada harian lokal NewsdeZimbabwe, kepolisian mengklaim kasus pemerkosaan anak-anak meningkat tajam sejak 2010, dari 2883 kasus menjadi 3172 di tahun berikutnya. Dalam banyak kasus, pelakunya berasal dari lingkungan keluarga. Sebuah rumah sakit di Harare mengabarkan telah menangani lebih dari 30.000 bocah korban pemerkosaan dalam periode empat tahun; (5) Amerika Serikat. "Akan ada 500.000 bayi lahir tahun ini di Amerika Serikat yang akan menjadi korban pelecehan seksual sebelum mereka berusia 18 tahun," tulis Children Assessment Centre (CAC). Menurut data Departemen Kesehatan, 16\% remaja antara 14 hingga 17 tahun mengaku pernah menjadi korban pelecehan seksual atau pemerkosaan. 
Walaupun tidak termasuk dalam daftar negara dengan tingkat pelecehan seksual anak tertinggi di dunia, Indonesia mencatat kemunduran dalam hal perlindungan anak. Komisi Nasional Perlindungan Anak mencatat, 2014 silam dari 2.726 kekerasan terhadap bocah, 56\% di antaranya berupa pelecehan seksual. Dari jumlah tersebut cuma 179 yang mengadu kepada Lembaga Perlindungan Saksi dan Korban. Para pelaku pedofilia bahkan bukan saja berasal dari warga negara Indonesia itu sendiri, namun juga berasal dari warga luar negeri. Sejak awal tahun 2017, imigrasi Indonesia telah menangkal 107 terduga kasus kejahatan seksual kepada anak atau pedofilia di mana 92 diantaranya berasal dari Australia. Seperti pada Oktober 2016, pengadilan negeri Denpasar menjatuhkan vonis 15 tahun penjara terhadap warga Australia, Robert Ellis, karena terbukti bersalah melakukan kejahatan pedofilia terhadap 11 anak perempuan dari usia 7 hingga 17 tahun. Hal ini memperlihatkan kepada kita bahwa Indonesia dipandang sebagai 'Lahan Subur' bagi para pelaku pedofilia untuk melancarkan aksi mereka dan juga sebagai sentakan kepada seluruh warga Indonesia bahwa, khususnya para penegak hukum bahwa regulasi dan pelindungan anak di Indonesia masih tergolong lemah.

\section{Rumusan Masalah}

Berdasarkan latar belakang yang telah diuraikan sebelumnya, artikel ini fokus pada kajian satu telaah tentang faktor-faktor apakah yang mempengaruhi penegakan hukum terhadap kejahatan pedofilia?

\section{HASIL DAN PEMBAHASAN}

\section{Penegakan Hukum}

Penegakan hukum adalah proses dilakukannya upaya untuk tegaknya atau berfungsinya normanorma hukum secara nyata sebagai pedoman perilaku dalam kehidupan bermasyarakat dan bernegara. Secara konsepsi, maka inti dan arti Penegakan hukum terletak pada kegiatan menyerasikan hubungan nilai-nilai yang terjabarkan di dalam kaidah-kaidah yang mantap dan mengejawantah dan sikap tindak sebagai rangkaian penjabaran nilai tahap akhir, untuk menciptakan, memelihara, dan mempertahankan kedamaian pergaulan hidup (Soerjono S, 2011).

Hukum merupakan aturan untuk mengatur masyarakat karena itu hukum harus dapat mengikuti irama perkembangan masyarakat. Salah satu faktor yang mempengaruhi penegakan hukum dalam masyarakat adalah kesadaran hukum masyarakat itu sendiri. Faktor kesadaran hukum ini sangat memainkan peran penting dalam penegakan hukum. Artinya semakin lemah tingkat kesadaran masyarakat semakin lemah pula kepatuhan hukumnya sebaliknya semakin kuat kesadaran hukumnya semakin kuat pula faktor kepatuhan hukum. Terdapat empat indikator kesadaran hukum, yang masing-masing merupakan suatu tahapan bagi tahapan-tahapan berikutnya, yaitu: (a) Pengetahuan hukum; (b) Pemahaman hukum; (c) Sikap hukum; dan (d) Pola perilaku hukum (H.R. Otje Salman \& Anthon F.S., 2008).

Upaya penegakan hukum terhadap para pedofilia serta pelaksanaan pelindungan terhadap anak, terhadap beberapa hambatan dalam pelaksanannya, yaitu (Arif Gosita, 1993):

1. Pengertian-Pengertian. Ada perbedaan pandangan dengan keyakinan yang kuat yang berkaitan dengan masalah perlindungan anak seorang individu, kelompok organisasi swasta atau pemerintah. Hal ini berkaitan erat latar belakang pendidikan, kepentingan, nilai-nilai sosial kepribadian yang bersangkutan. Jadi perlu adanya usaha mengatasi hambatan dalam amsalah pemilikan pemgertian yang tepat mengenai perlindungan anak, misalnya melalui pendidikan, penyuluhan, dll. Pengembangan pengertian yang tepat merupakan dasar seseorang mau ikut berpartisipasi dalam kegiatan perlindungan anak. 
2. Masalah Kepentingan dan Kewajiban. Keberhasilan usaha perlindunga anak sedikit banyak bergantung pada kesediaan dan kemampuan untuk memperjuangkan kepentingan diri sendiri dan kepentingan orang lain. Hal ini berkaitan erat dengan kerelaan seseorang untuk mengutamakan kepentingan anak di atas kepentingan pribadi, berdasarkan keyakinan bahwa akhirnya pelayanan kepentingan anak, kepentingan nasional juga akan membawa dampak positif pada pamanuhan kepentingan pribadi. Apabila keyakinan ini tidak merata pada banyak anggota maka dikhawatirkan banyak anggota masyarakat tidak akan merasa berkewajiban ikut serta dalam mengembangkan kemmampuan anak untuk melindungi dirinya sendiri secara wajar adan legal, dengan juga memperhatikan kepentingan orang lain.

3. Masalah Kerjasama dan Koordinasi. Perlindungaan anak adalah suatu hasil interaksi karena adanya interelasi antara fenomena yang ada dan saling mempengaruhi. Maka ini berarti dalam pengadaan dan pelaksanaan perlindungan anak yang memuaskan diperlukan sekali kerjasama dan koordinasi dari kerjasama tersebut. Tanpa adanya kerjasama dan koordinasi yang baik antara yang bersangkutan dan berkepentingan, maka kegiatan perlindungan anak akan dihambat perkembangannya dengan akibat tambahan gangguan ketertiban, keamanan dan pembangunan nasional.

4. Masalah Jaminan Hukum. Pelaksanaan perlindungan anak belum dijamin dengan peraturan perundang-undangan yang mantap, sehingga menghambat pelaksanaan perlindungan anak secara memuaskan. Undang-undang yang menyangkut kepentingan anak belum tegas menyatakan bagaimana perlindungan anak itu dilaksanakan secara kongkrit dan apa akibatnya jika seseorang tidak meakukan perlindungan anak.

\section{Dampak Bagi Anak serta Sanksi Bagi Tindak Kejahatan Pedofilia}

Ketika kita mengalami kejadian yang membuat stress dan kecemasan berulang, kita mulai mengembangkan pola-pola perilaku dan kognisi yang dirancang untuk menghindarkan atau sebaliknya meredakan masalah, seperti kewaspadaan, perilaku melarikan diri, dan pemikiran defensive. Ini semua bisa berubah menjadi sekumpulan sikap yang pada dasarnya menghasilkan rasa cemas, marah, sedih, dan lain sebagainya (C. George Boeree, 2008). Anak kecil masih berada dalam proses mempelajari keterampilan-keterampilan yang dibutuhkan untuk hidup dan berkembang di dalam dunia sosial, dank arena itu ia lebih rentan terkena stres. Ada banyak peristiwa penuh tekanan yang bisa menimpa anak-anak, remaja, dan bahkan orang dewasa yang secara emosional sangat stabil dan sangat terdidik. Peristiwa penuh tekanan tersebut bisa berbentuk kematian orang tua, perceraian dan perkawinan kembali, anak angkat, institusionalisasi, kesehatan anak atau orang tua yang buruk, pengalaman masa perang, imigrasi, kemiskinan dan ketunawismaan, serangan, pelecehan seksual, fanatisme, dan lain-lain (C. George Boeree, 2008). Gangguan stres pasca-traumatik dan akut mengacu pada kecemasan dan gangguan perilaku yang berkembang dalam bulan pertama setelah penyingkapan trauma ekstrem. Umunya, gejala stress akut bermula selama atau sesaat setelah trauma. Kejadian traumatic ekstrem tersebut mencakup perkosaan atau penyerangan fisik parah lainnya, pengalaman hampir mati dalam kecelakaan, menyaksikan pembunuhan, dan pertempuran (C. George Boeree, 2008).

Menurut Stephen Schafer yang membagi tipologi korban, Biologically weak victims, adalah mereka yang mempunyai bentuk fisik atau mental tertentu yang menyebabkan orang melakukan kejahatan terhadapnya. Misalnya anak kecil, orang lanjut usia, orang cacat, orang yang sakit mental atau gila dan lainnya (Muhadar, 2006). Maka dari itu, posisi anak sebagai korban di sini adalah korban yang rentan atau karena kondisi fisik yang lemah tidak berdaya dan tidak bisa melawan menyebabkan anak menjadi sasaran utama tindak pidana pedofilia. Adapun dampak terhadap anak/korban pedofilia sebagaimana pendapat yang dikemukakan oleh dalam "Likuliku Seks Menyimpang, Bagaimana Solusinya" adalah sebagai berikut (Nur Hidayati, 2014): 
1. Tanda-tanda perilaku:

a. Perubahan-perubahan mendadak pada perilaku dari bahagia ke depresi atau permusuhan, dari bersahabat ke isolasi, atau dari komunikatif ke penuh rahasia

b. Gangguan tidur, takut pergi ke tempat tidur, sulit tidur atau terjaga dalam waktu yang lama, mimpi buruk

c. Perilaku menghindar, takut akan atau menghindar dari orang tertentu (orang tua, kakak, saudara lain, tetangga/pengasuh), lari dari rumah, nakal atau membolos sekolah

2. Tanda-tanda Kognisi:

a. Tidak dapat berkonsentrasi, sering melamun dan menghayal, focus perhatian singkat/terpecah)

b. Minat sekolah memudar, menurunnya perhatian terhadap pekerjaan sekolah dibandingkan dengan sebelumnya

c. Respons reaksi berlebihan, khususnya terhadap gerakan tiba-tiba dan orang lain dalam jarak dekat

3. Tanda-tanda sosial dan emosional:

a. Rendahnya kepercayaan diri, perasaan tidak berharga

b. Menarik diri: mengisolasi diri dari teman, lari ke dalam khalayan atau ke bentukbentuk lain yang tidak berhubungan

c. Ketakutan berlebihan: kecemasan, hilang kepercayaan terhadap orang lain

4. Tanda-tanda fisik:

a. Luka-luka pada alat kelamin atau mengidap penyakit kelamin

b. Perasaan sakit yang tidak jelas, sakit kepala, sakit perut, berat badan turun dan sering muntah-muntah

c. hamil

Pedofilia digolongkan sebagai kejahatan terhadap anak karena mengakibatkan dampak buruk bagi korban. Menurut ahli kejiwaan anak Seto Mulyadi, para korban pedofilia akan mengalami kurang rasa percaya diri dan memilki pandangan negative terhadap seks. Para pedofilis memiliki kecenderungan untuk melakukan hubungan seksual dengan anakanak. Baik anak lakilaki di bawah umur (pedofilia homoseksual) dan ataupun dengan anak perempuan di bawah umur (pedofilia heteroseksual) (Nur Hidayati, 2014). Pedofilia merupakan bentuk penyiksaan anak di mana orang dewasa atau remaja yang lebih tua menggunakan anak sebagai rangsangan seksual. Adapun efek kekerasan seksual terhadap anak antara lain: depresi, gangguan stres pasca trauma dan kegelisahan. Namun, dampak psikologis yang dihadapi oleh masing-masing korban kekerasan seksual tidak sama, karena memiliki kepribadian, cara mengatasi masalah, cara memanipulasi kognisi, serta dukungan sosial yang berbeda. Meskipun dampaknya berbeda, namun secara umun hasil penelitian ini menunjukkan adanya perilaku traumatis pada korban kekerasan seksual. Perilaku traumatis tersebut adalah Post Traumatic Stress Disorder (PTSD) (M. Anwar Fuadi, 2011).

Faulkner (2003) menjelaskan bahwa upaya untuk mengatasi kekerasan seksual harus dilakukan secara terus menerus melalui langkah-langkah sebagai berikut: (a) korban harus menyadari bahwa peristiwa kekerasan terjadi bukan karena kesalahan mereka; (b) korban juga harus menyadari bahwa mereka tidak sendirian, ada banyak orang yang mengalami peristiwa seperti mereka, sehingga peluang untuk memperoleh bantuan juga sangat besar; (c) korban perlu melaporkan peristiwa tersebut pada orang lain yang memperoleh bantuan sampai ada yang dapat memperoleh perlindungan; (d) tindakan abuse terhadap anak harus segera dilaporkan pada yang berwajib dan perlu segera mencari bantuan professional; (e) korban jangan mencoba untuk 538 
mengatasinya sendiri; (f) korban perlu menghindari layanan konseling online, karena para pelaku abuse juga mengunjungi forum online, perlu diingat bahwa, tidak melaporkan tindakan abuse adalah sama halnya dengan mendukung terjadinya tindakan tersebut dan hal ini merupakan bentuk tindakan kriminal juga (Zahra, 2007).

Berdasarkan kenyataan kejahatan terhadap anak (pedofilia) harus ditanggulangi dengan hukum pidana. Kebijakan hukum pidana dalam rangka untuk melindungi obyek kejahatan sudah diterapkan dalam KUHP (Kitab Undan-undang Hukum Pidana). Dalam KUHP adanya ketentuan tentang larangan melakukan persetubuhan dengan wanita di luar perkawinan dan belum berusia 15 tahun (Pasal 287); larangan perbuatan cabul bagi orang dewasa dengan orang lain sesama jenis dan belum dewasa (Pasal 292); larangan berbuat cabul dengan anaknya, anak tirinya, anak angkat, atau anak dibawah perwalian yang belum dewasa (Pasal 294); larangan menelantarkan anak dibawah tujuh tahun dengan maksud untuk melepaskan tanggung jawab (Pasal 305 Jo. Pasal 306 dan Pasal 307); larangan merampas nyawa seorang anak segera setelah dilahirkan oleh ibu (Pasal 341 Jo. Pasal 342). Ternyata ketentuan-ketentuan tersebut belum cukup memadai untuk mencegah dan mengatasi bentuk perlakuan atas anak sebagai obyek kejahatan.

Kemudian ketentuan tentang perlindungan anak dari obyek kejahatan tersebut dilengkapi dan ditambah dengan lahirnya UU No. 23 tahun 2002 tentang Perlindungan Anak yang termuat dalam Bab XII yaitu mulai Pasal 77 sampai dengan Pasal 90 serta UU No. 39 tahun 1999 tentang HAM Pasal 65 mengatur adanya hak anak untuk mendapatkan perlindungan dari kegiatan eksploitasi dan pelecehan seksual, penculikan, perdagangan anak serta dari berbagai bentuk penyalahgunaan narkotika, psikotropika, dan zat adiktif lainnya. UU No. 23 tahun 2002 Pasal 88 mengatur adanya ketentuan pidana bagi setiap orang yang mengeksploitasi ekonomi ataupun seksual anak dengan maksud menguntungkan diri sendiri atau orang lain, dipidana dengan pidana penjara paling lama 10 tahun dan/atau denda paling banyak Rp 200.000.000,00 (dua ratus juta rupiah). Adanya kasus penyimpangan seksual seperti pedofilia ibarat gunung es menunjukkan perlunya perlindungan khusus bagi anak yang dieksploitasi secara seksual yang menjadi tanggung jawab pemerintah dan masyarakat. Sebagaimana diatur dalam Pasal 66 ayat

(2) UU No. 23 tahun 2002. Perlindungan khusus bagi anak yang dieksploitasi dilakukan melalui:

1. Penyebarluasan dan/atau sosialisasi ketentuan peraturan perundang-undangan yang berkaitan dengan perlindungan anak yang dieksploitasi secara ekonomi dan/atau seksual,

2. Pemantauan, pelaporan, dan pemberian sanksi, dan

3. Pelibatan berbagai instansi pemerintah, perusahaan, serikat pekerja, lembaga swadaya masyarakat, dan masyarakat dalam penghapusan eksploitasi terhadap anak secara ekonomi dan/atau seksual.

Dalam rangka meningkatkan efektifitas penyelenggaran perlindungan anak dengan UU No. 23 tahun 2002 ini dibentuk Komisi Perlindungan Anak Indonesia (KPAI) yang bersifat independen. Keanggotaan KPAI terdiri dari unsur pemerintah, tokoh agama, tokoh masyarakat, dunia usaha dan kelompok masyarakat yang peduli terhadap perlindungan anak sebagaimana diatur Pasal 74 ayat (2). Adapun menurut Pasal 1 butir 1 Undang-Undang Nomor 44 Tahun 2008 Tentang Pornografi, Pornografi adalah gambar, sketsa, ilustrasi, foto, tulisan, suara, bunyi, gambar bergerak, animasi, kartun, percakapan, gerak tubuh, atau bentuk pesan lainnya melalui berbagai bentuk media komunikasi dan/atau pertunjukan di muka umum, yang memuat kecabulan atau eksploitasi seksual yang melanggar norma kesusilaan dalam masyarakat.

Namun dengan maraknya kasus pedofilia di negeri ini, pemerintah menilai perlu adanya perubahan pada Undang-Undang Nomor 23 Tahun 2002 tentang Perlindungan Anak sebagaimana telah diubah dengan Undang-Undang Nomor 35 Tahun 2014 tentang Perubahan atas Undang-Undang Nomor 23 Tahun 2002 tentang Perlindungan Anak. Oleh karena itu, 
Presiden Joko Widodo pada 26 Mei 2016 telah menandatangani Peraturan Pemerintah Pengganti Undang-Undang (Perppu) Nomor 1 Tahun 2016 tentang Perubahan Kedua Atas Undang-Undang Nomor 23 Tahun 2002 tentang Perlindungan Anak. Berikut adalah ketentuan sanksi yang diubah dari UU Nomor 23 Tahun 2002, Pasal 81 Undang-Undang Nomor 23 Tahun 2002 diubah, sehingga rumusannya menjadi:

1. Setiap orang yang melanggar ketentuan sebagaimana dimaksud dalam Pasal 76D (setiap orang dilarang melakukan Kekerasan atau ancaman Kekerasan memaksa Anak melakukan persetubuhan dengannya atau dengan orang lain) dipidana dengan pidana penjara paling singkat 5 (lima) tahun dan paling lama 15 (lima belas) tahun dan denda paling banyak Rp5.000.000.000,00 (lima miliar rupiah);

2. Ketentuan pidana sebagaimana dimaksud pada ayat (1) berlaku pula bagi setiap Orang yang dengan sengaja melakukan tipu muslihat, serangkaian kebohongan, atau membujuk Anak melakukan persetubuhan dengannya atau dengan orang lain;

3. Dalam hal tindak pidana sebagaimana dimaksud pada ayat (1) dilakukan oleh orang tua, wali, orang-orang yang mempunyai hubungan keluarga, pengasuh anak, pendidik, tenaga kependidikan, aparat yang menangani perlindungan anak, atau dilakukan oleh lebih dari satu orang secara bersama-sama, pidananya ditambah 1/3 (sepertiga) dari ancaman pidana sebagaimana dimaksud pada ayat (1);

4. Selain terhadap pelaku sebagaimana dimaksud pada ayat (3), penambahan $1 / 3$ (sepertiga) dari ancaman pidana juga dikenakan kepada pelaku yang pernah dipidana karena melakukan tindak pidana sebagaimana dimaksud dalam Pasal 76D;

5. Dalam hal tindak pidana sebagaimana dimaksud dalam Pasal 76D menimbulkan korban lebih dari 1 (satu) orang, mengakibatkan luka berat, gangguan jiwa, penyakit menular, terganggu atau hilangnya fungsi reproduksi, dan/atau korban meninggal dunia, pelaku dipidana mati, seumur hidup, atau pidana penjara paling singkat 10 (sepuluh) tahun dan paling lama 20 (dua puluh) tahun;

6. Selain dikenai pidana sebagaimana dimaksud pada ayat (1), ayat (3), ayat (4), dan ayat (5), pelaku dapat dikenai pidana tambahan berupa pengumuman identitas pelaku;

7. Terhadap pelaku sebagaimana dimaksud ayat (4) dan ayat (5) dapat dikenai tindakan berupa kebiri kimia dan pemasangan pendeteksi elektronik;

8. Tindakan sebagaimana dimaksud pada ayat (7) diputuskan bersama-sama dengan pidana pokok dengan memuat jangka waktu pelaksanaan tindakan;

9. Pidana tambahan dan tindakan dikecualikan bagi pelaku Anak.

Adapun di antara Pasal 81 dan Pasal 82 disisipkan 1 (satu) pasal yakni Pasal 81A yang isi ketentuannya sebagai berikut:

1. Tindakan sebagaimana dimaksud dalam Pasal 81 ayat (7) (dikenai pidana tambahan berupa pengumuman identitas pelaku) dikenakan untuk jangka waktu paling lama 2 (dua) tahun dan dilaksanakan setelah terpidana menjalani pidana pokok;

2. Pelaksanaan tindakan sebagaimana dimaksud pada ayat (1) di bawah pengawasan secara berkala oleh kementerian yang menyelenggarakan urusan pemerintahan di bidang hukum, sosial, dan kesehatan;

3. Pelaksanaan kebiri kimia disertai dengan rehabilitasi;

4. Ketentuan lebih lanjut mengenai tata cara pelaksanaan tindakan dan rehabilitasi diatur dengan Peraturan Pemerintah.

Ketentuan Pasal 82 diubah sehingga isi ketentuannya sebagai berikut:

1. Setiap orang yang melanggar ketentuan sebagaimana dimaksud dalam Pasal 76E (setiap orang dilarang melakukan Kekerasan atau ancaman Kekerasan, memaksa, melakukan tipu muslihat, melakukan serangkaian kebohongan, atau membujuk Anak untuk melakukan atau membiarkan dilakukan perbuatan cabul) dipidana dengan pidana penjara paling singkat 5 
(lima) tahun dan paling lama 15 (lima belas) tahun dan denda paling banyak Rp5.000.000.000,00 (lima miliar rupiah);

2. Dalam hal tindak pidana sebagaimana dimaksud pada ayat (1) dilakukan oleh orang tua, wali, orang-orang yang mempunyai hubungan keluarga, pengasuh anak, pendidik, tenaga kependidikan, aparat yang menangani perlindungan anak, atau dilakukan oleh lebih dari satu orang secara bersama-sama, pidananya ditambah $1 / 3$ (sepertiga) dari ancaman pidana sebagaimana dimaksud pada ayat (1);

3. Selain terhadap pelaku sebagaimana dimaksud pada ayat (2), penambahan $1 / 3$ (sepertiga) dari ancaman pidana juga dikenakan kepada pelaku yang pernah dipidana karena melakukan tindak pidana sebagaimana dimaksud dalam Pasal 76E;

4. Dalam hal tindak pidana sebagaimana dimaksud dalam Pasal 76E menimbulkan korban lebih dari 1 (satu) orang, mengakibatkan luka berat, gangguan jiwa, penyakit menular, terganggu atau hilangnya fungsi reproduksi, dan/atau korban meninggal dunia, pidananya ditambah $1 / 3$ (sepertiga) dari ancaman pidana sebagaimana dimaksud pada ayat (1);

5. Selain dikenai pidana sebagaimana dimaksud pada ayat (1) sampai dengan ayat (4), pelaku dapat dikenai pidana tambahan berupa pengumuman identitas pelaku;

6. Terhadap pelaku sebagaimana dimaksud pada ayat (2) sampai dengan ayat (4) dapat dikenai tindakan berupa rehabilitasi dan pemasangan alat pendeteksi elektronik;

7. Tindakan sebagaimana dimaksud pada ayat (6) diputuskan bersama-sama dengan pidana pokok dengan memuat jangka waktu pelaksanaan tindakan;

8. Pidana tambahan dikecualikan bagi pelaku Anak.

Di antara Pasal 82 dan Pasal 83, menurut Perppu ini, disisipkan 1 (satu) pasal yakni Pasal 82A yang isi ketentuannya sebagai berikut (Setkab, 2016):

1. Tindakan sebagaimana dimaksud dalam Pasal 82 ayat (6) (dilaksanakan selama dan/atau setelah terpidana menjalani pidana pokok;

2. Pelaksanaan tindakan sebagaimana dimaksud pada ayat (1) di bawah pengawasan secara berkala oleh kementerian yang menyelenggarakan urusan pemerintahan di bidang hukum, sosial, dan kesehatan;

3. Ketentuan lebih lanjut mengenai tata cara pelaksanaan tindakan diatur dengan Peraturan Pemerintah.

Perppu Nomor 1 Tahun 2016 ini sering kali dijuluki sebagai perppu kebiri dimana sebagaimana telah disampaikan pada Pasal 81A ayat (3) disisipkan ketentuan tentang pelaksanaan kebiri kimia kepada para pelaku. Dimana sanksi tersebut merupakan hal baru yang dan tentu saja asing bagi masyarakat Indonesia. Menurut Nugroho Setiawan, dokter spesialis andrologi di Rumah Sakit Umum Pusat Fatmawati, Jakarta Selatan, kebiri kimia ialah penyuntikan zat antitestosteron ke tubuh pria untuk menurunkan kadar hormon testosteron, yang sebagian besar diproduksi sel lydig di dalam buah zakar. Masuknya zat anti-testosteron ke dalam tubuh, menurut dokter Nugroho, praktis membuat gairah seksual menurun (Jerome Wirawan, 2016). Namun di negara lain, hukuman kebiri ini bukanlah hal baru dan telah diterapkan dari beberapa tahun silam. Berikut beberapa negara yang juga menerapkan sanksi tersebut (Pusat Data Republika , 2015):

1. Amerika Serikat, Hukuman kebiri secara kimiawi bagi pelaku kejahatan seksual terhadap anak sejak 1996.

2. Polandia, Penerapan hukum kebiri dilakukan secara paksa terhadap pelaku yang telah dinyatakan bersalah oleh pengadilan sejak 2010.

3. Moldova, Hukuman kebiri bagi pelaku kejahatan seksual anak sejak 2012.

4. Estonia, Hukuman kebiri kimiawi dengan menekan libido pelaku kejahatan seks terutama kepada pelaku pedofil. 
5. Israel, Penerapan hukum kebiri bagi pelaku kejahatan seksual terhadap anak. Namun, harus ada pernyataan sukarela dari pelaku.

6. Argentina, Hukum kebiri harus ada pernyataan sukarela dari pelaku kejahatan seksual terhadap anak dan pelaku yang dikebiri mendapatkan keringanan hukuman.

7. Australia, Hukum kebiri diterapkan sejak 2010 bagi pelaku yang menyatakan sukarela untuk dikebiri.

8. Korea Selatan, Hukum kebiri kimiawi diterapkan sejak 2011 bagi pelaku kejahatan seksual anak.

9. Rusia, Hukuman kebiri yang berlaku di Rusia wajib dilakukan oleh setiap pelaku yang dinyatakan bersalah oleh pengadilan.

Dari apa yang telah dijabarkan tersebut, maka dapat ditarik kesimpulan bahwa sanksi bagi pelaku tindak pidana pedofilia telah diatur diberbagai negara sesuai ketentuan hukum masingmasing negara. Melihat hukuman kebiri yang telah diterapkan diberbagai negara bagi pelaku tindak pidana pedofilia menjadi sewajarnya bila negara Indonesia juga menerapkan hukuman kebiri tersebut. Hal ini juga telah diatur dalam Pasal 81A ayat (3) Perppu Nomor 1 Tahun 2016 yangmana dalam Pasal tersebut disisipkan ketentuan tentang pelaksanaan kebiri kimia kepada para pelaku sehingga Perppu ini sering kali dijuluki sebagai Perppu kebiri. Namun, tentu terdapat hukuman lain selain hukuman kebiri untuk pelaku tindak pidana pedofilia, yakni tercantum pada UU Perlindungan anak yang mana terdapat beberapa pasal yang secara tegas dapat dikenakan sanksi baik denda maupun pidana penjara serta hukuman kebiri khususnya kebiri kimia dapat diterapkan dan digunakan sebagai alternative sanksi pidana bagi pelaku pedofilia di Indonesia. Dari sejarah Negara yang telah menerapkan hukuman kebiri ini, hukuman tersebut efektif mengurangi tindak pidana kejahatan seksual terhadap anak dan pemerkosaan. Efektifnya hukuman ini terbukti dengan berkurangnya tingkat kejahatan tersebut sehingga dengan kata lain hukuman kebiri ini bisa memberika efek jera bagi pelaku tindak pidana pedofilia dan mencegah terjadinya tindak pidana yang sama.

\section{KESIMPULAN}

Pedofilia merupakan aktivitas perilaku penyimpangan dengan menggunakan pencabulan anak untuk memperoleh kepuasan seksual atau mengekspresikan kepentingan seksualnya. Penegakan hukum pidana untuk menangguLangi pedofilia sebagai perilaku yang menyimpang harus terus dilakukan karena pedofilia merupakan ancaman yang nyata terhadap norma-norma sosial yang dapat menimbulkan ketegangan individual maupun ketegangan-ketegangan sosial. Pedofiiia merupakan ancaman riil atau potensiil bagi berlangsungnya ketertiban sosial. Upaya hukum pidana dalam menanggulangi kejahatan pedofilia masih menggunakan KUHP sebagai dasar untuk melakukan pemidanaan terhadap pelaku/pembuat walaupun Undang-Undang No. 23 Tahun 2002 tentang Perlindungan Anak telah diterbitkan. Hal ini dikarenakan peraturan perundang-undangan tersebut tidak membuat peraturan atau ketentuan yang bersifat khusus atau menyimpang dari KUHP. Kebijakan formulasi hukum pidana dalam menanggulangi kejahatan pedofilia dimasa yang akan datang sudah termuat secara khusus pada Buku II sub bab tentang Perkosaan dan Perbuatan Cabul Pasal 489 sampai dengan Pasal 498 Konsep KUHP.

\section{Ucapan terima kasih.}

Penulis mengucapkan terima kasih kepada berbagai pihak yang telah membantu dalam penelitian ini.

\section{REFERENSI}


Anggadewi, B. E.T. (2007). Studi kasus tentang dampak psikologis anak korban kekerasan dalam keluarga. Makalah. Fakultas Psikologi Universitas Sanata Dharma. Yogyakarta.

Boeree, C. G. (2008). General psychology: Psikologi kepribadian, persepsi, kognisi, emosi \& perilaku. Jogjakarta: Prismasophie

Gosita, A. (1993). Masalah korban kejahatan, kumpulan karangan Cetakan ke-3. Jakarta: CV Akademika Pressindo

Indonesia, Undang-Undang Nomor 23 Tahun 2002 tentang Perlindungan Anak (Lembaran Negara Republik Indonesia Tahun 2014 Nomor 297, Tambahan Lembaran Negara Republik Indonesia Nomor 5606).

Indonesia, Undang-Undang Nomor 44 Tahun 2008 Tentang Pornografi (Lembaran Negara Republik Indonesia Tahun 2008 Nomor 181, Tambahan Lembaran Negara Republik Indonesia Nomor 4928).

Indonesia, Peraturan Pemerintah Pengganti Undang-Undang Republik Indonesia Nomor 1 Tahun 2016 Tentang Perubahan Kedua Atas Undang-Undang Nomor 23 Tahun 2002 Tentang Perlindungan Anak (Lembaran Negara Republik Indonesia Tahun 2016 Nomor 99, Tambahan Lembaran Negara Republik Indonesia Nomor 5882).

Muhadar. (2006). Viktimisasai kejahatan pertanahan, edisi revisi. Yogyakarta: LaksBang PRESSindo

Hidayati, N. (2014). perlindungan anak terhadap kejahatan kekerasan seksual (pedofilia). Ragam Jurnal Pengembangan Humaniora. 14(1). 68-73

Salman, O. (2008). Beberapa Aspek sosiologi hukum Cetakan ke-2. Bandung: PT. Alumni

Soekanto, S. (2011). Faktor-faktor yang mempengaruhi penegakan hukum. Jakarta: PT RajaGrafindo Persada

Zahra, P. R. (2007). Kekerasan seksual pada anak. ARKHE, Jurnal Ilmiah Psikologi, 12(2) 10-15 